Kosztopulosz Andreász - Kuruczleki Éva (szerk.) (2020): Társadalmi és gazdasági

folyamatok elemzésének kérdései a XXI. században. Szegedi Tudományegyetem

Gazdaságtudományi Kar, Szeged, https://doi.org/10.14232/tgfek21sz.9

\title{
A területi tőke és a családi vállalkozások kapcsolatának vizsgálata
}

\author{
Polster Csilla
}

A tanulmány célja annak vizsgálata, hogy milyen kapcsolat figyelhetö meg egy régió területi tökéje és az ott müködö családi vállalkozások között.

Ahhoz, hogy a családi vállalkozások és a területi töke bizonyos elemei közötti kölcsönhatásról átfogó képet kapjunk, a tanulmány egyrészt a kutatási területek tudományos irodalmára, a korábbi kutatásokra épül. Másrészt két üzleti tanulmány kerül bemutatásra, amelyeknek alapját a családi vállalkozásokkal készitett mélyinterjúk adják.

A vizsgált családi vállalkozások esetén még nem zajlott le a generációváltás. Az elemzett családi vállalkozások a ZitaTextil Bt. és az Épületcenter Kft.. A kutatás eredményeképpen a tanulmány példát ad a területi tőke társadalmi és kulturális hatásaira a családi vállalkozásokra, valamint a családi vállalkozások növekvő erejére a területi tőkére vonatkozásban. A vállalati regionális szerepvállalás és a beágyazottság, valamint a területi tőke között erös kölcsönhatás mutatkozik.

Kulcsszavak: területi tőke, családi vállalkozások, beágyazottság, kölcsönhatás, györi régió

\section{Bevezetés}

A kutatás célja annak vizsgálata, hogy milyen kölcsönhatás figyelhető meg egy régió területi tőkéje és az ott müködő generációváltás előtt álló családi vállalkozások között.

A kutatás újszerüségét az adja, hogy korábban még nem vizsgálták a generációváltás hatását a vállalkozás beágyazottságára, területi tőkéjére vonatkozóan.

Bár a családi vállalkozások régóta jelen vannak Magyarországon, többségüket a rendszerváltás körül alapították, a családi vállalkozásokkal kapcsolatos kutatások az elmúlt években kezdődtek el intenzíven.

Ahhoz, hogy a családi vállalkozások és a területi tőke bizonyos elemei közötti kölcsönhatásról átfogó képet kapjunk, a dolgozat egyrészt a kutatási területek tudományos irodalmára, a korábbi kutatásokra épül. Másrészt üzleti tanulmányok kerülnek bemutatásra, amelyeknek alapját a családi vállalkozások tulajdonosaival készített mélyinterjúk adják.

A kutatás eredményeképpen a dolgozat példát ad a területi töke családi vállalkozásokra gyakorolt hatásaira, valamint a családi vállalkozások növekvő erejére a területi tőkére vonatkozóan. A vállalati regionális szerepvállalás és a beágyazottság, valamint a területi tőke között erös kölcsönhatás mutatkozik.

A dolgozatban bemutatásra kerülnek a családi vállalkozás különböző megközelítései. Miután meghatároztam a családi vállalkozások koncepcióját és gazdasági jelentőségét, áttekintem a családi vállalkozásokat érintő trendeket és kulcskérdéseket. Ezután áttekintést adok a társadalmi tőkéről és a kulturális tőkéről. Ennek a kutatásnak a keretein belül arra törekedtem, hogy feltárjam a társadalmi és a kulturális tőke hatásait a családi vállalkozásokra. 
A megkérdezett elődök és utódok az interjúkban őszintén szóltak a régió társadalmi és a kulturális tőkéjére vonatkozóan. A régió társadalmi tőkéjéhez kapcsolódóan megismerhettem a vállalkozás helyi szintü hálózatait, kapcsolatait és tevékenységét, az önkormányzattal fenntartott kapcsolatát, társadalmi szervezetekhez való viszonyulását, a régióba való beágyazottságát, illetve regionális kötődését. A régió kulturális tőkéjére vonatkozóan feltérképezhettem a vállalkozás kapcsolatát oktatási és kulturális intézményekkel, oktatási és kulturális életre való hatását, közösségépítését, illetve innovációs életre ható impulzusát.

\section{Szakirodalmi áttekintés}

Ebben a fejezetben a témához kapcsolódó legfontosabb fogalmak néhány aspektusa kerül bemutatásra.

\subsection{Családi vállalkozások}

Az Európai Bizottság (Csákné 2012, in: Európai Bizottság 2009) által közzétett definíció a családi vállalkozásokra vonatkozóan az alábbi: egy vállalkozás a családi vállalkozások közé sorolható a méretétől függetlenül, ha

- a döntési jogok többsége az alapító, az ő szülei, gyermekei vagy rokonai kezében van,

- legalább egy családtag vagy egy tag a rokonságból formálisan is beleszól a múködésbe,

- tőzsdén jegyzett cégek akkor, ha a részvények több, mint $25 \%$-a a vállalkozás alapítója vagy megvásárlója, illetve az említett két típusú személy családja vagy leszármazottai kezében van.

A családi vállalkozásokban két rendszer összefonódik: család és cég. A családok részvétele a vállalatnál különböző mértékű lehet, gyakran a szakmai menedzsmentet bíznak meg az irányítással. Ebben az esetben a rendszer "három tényezőjü" rendszerré válik: család, tulajdonosok, menedzsment (1. ábra). Az ábrán látható lehetséges szerepek között a 7-es szám jelöli azt a személyt, aki családtag, tulajdonos és vezető egy személyben (Konczosné 2015).

1. ábra A családi cégek három pillére

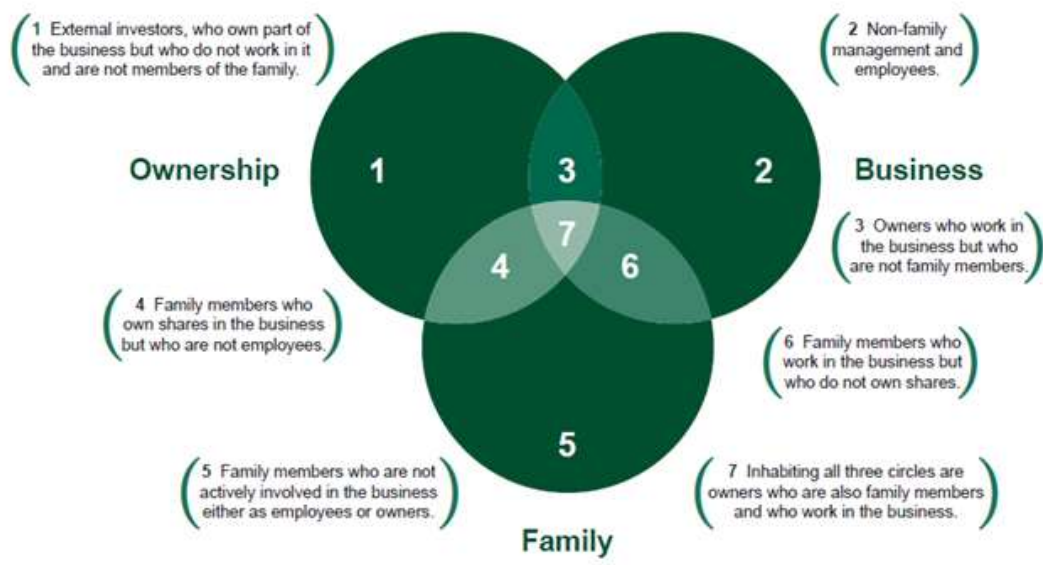

Forrás: Gersick és társai, 1997: 6 alapján saját szerkesztés 
A PricewaterhouseCoopers (2008) felmérésében azok a vállalkozások tekinthetők családi vállalkozásoknak, amelyekben a tulajdonlás legalább 51\% -a egy vagy több hozzátartozó család tulajdonában van, a felső vezetés többnyire családtagokból áll, és a tulajdonosok látják el a napi üzemeltetési folyamatot. (pwc.com)

\subsection{Társadalmi töke}

Rechnitzer (2016) leszögezi, hogy egy település egyedi jegyeit, jellegzetességeit szemlélteti a társadalmi tőke. Itt olyan kialakult normák, szabályok, kötelékek, formális és informális hálózatok összessége áll fenn, amelyek abból és abban a területrendszerben élnek, hatnak és müködnek, így válnak lényegében helyi közjószággá. Véleménye szerint ezek a meghatározottságok fellelhetőek mikroszinten az egyén és a közösségei, vagy éppen a vállalkozások, intézmények vonatkozásában, ám ezek más szabályokat követnek, mint a területrendszer által generáltak. Hasonlóan makroszinten is megfigyelhetők a kötődések, de ezek már inkább a társadalom egészére vonatkoznak, nem csak egy helyhez köthetők, de visszahatnak a lokális dimenziókra például abban, hogy meghatározzák a területi egységek müködését, az ottani források gyüjtését, kezelését, vagy éppen a választás rendszerét, a hely (város) fejlesztésének körülményeit. Rechnitzer megállapította, hogy a makroszintek követelményei, a mikroszintek adottságai a területi dimenzióban találkoznak, ott létrehozva a helyi közjószágot, amihez a társadalmi tőke is tartozik.

Nagy (2016) a társadalmi tőkéhez sorolja a társadalmi szereplők közötti kapcsolatokat, a normákat, az értékeket. Három jelentős személyiség megközelítését mutatja be: Nanlin, Field és Cox. Nanlin szemléletmódjából kiemeli a társadalmi tőke két szintre - egyének és csoportok szintjére - való bontását. Fieldnél azt látta, hogy Field a társadalmi tőkének három típusát különbözteti meg: az áthidaló (bridging), a megkötő (bonding) és az összekapcsoló (linking) társadalmi tőkét. Cox munkásságában azt találta érdekesnek, hogy nem csak egy bizonyos szintü társadalmi tőke elérésére kell törekednünk, hanem annak állandó növelésére. Cox véleményéböl a lényeges elemeket hangsúlyozza. Ezek a következők: a bizalom, az önbizalom, az interperszonális bizalom, a kormányba és az intézményekbe vetett bizalom; a reciprocitás; a tolerancia és a különbözőség; a részvétel és a kooperáció; a valahová tartozás; a vita és a megkérdőjelezés; a saját és a mások értékeinek erősítése, fokozása; a szociális adottságok, a lehetőségek. Nagy (2016) rávilágít arra is, hogy „,más szerzők azt hangsúlyozzák, hogy a bizalom, a szociális adottságok, az együttmüködés, a felismerés és a jóváhagyás a társadalmi tőke első számú komponensei, amik közvetlenül kapcsolódnak a részvételhez, az állampolgári elkötelezettséghez és a stabil demokráciához." (Nagy 2016, 39. o.)

\subsection{Kulturális tőke}

Rechnitzer rámutat, hogy a bizalom hiányának oldása a kulturális tőkéhez kapcsolódik. „A hely (város) kialakít tanulható munkakultúrát, életmód mintákat, fogyasztási modelleket, vagy éppen a szórakozást, a szabadidő eltöltés formáit. De felhalmozódnak a közösségekben tárgyiasult kulturális javak is, amiknek a megtartása, elismerése, integrálása a hétköznapok világában értéktudatot vagy egy más szemléletet testesít meg. 
Beszélhetünk még szimbólumokról, személyiségekről, szervezetekről, ezekhez kapcsolódó magatartásmódokról, viselkedési mintákról, amik szintén az adott hely, város sajátosságai” (Rechnitzer 2016, 22. o.).

A kulturális tőkéről szóló áttekintésben bemutatásra kerül a Bourdieu által használt kifejezés, amely a szimbólumokra, eszmékre, ízekre és preferenciákra utal, amelyeket stratégiai módon erőforrásokként használhatnak a társadalmi cselekvésben. Bourdieu ezt a kulturális tőkét "habitusnak" tekinti, megtestesült szocializált hajlandóság vagy hajlam arra, hogy valamilyen módon cselekedjen, gondoljon vagy érezze magát. (oxfordreference.com)

\section{Kutatás módszertana, kutatási kérdések, interjúk elemzése}

Ebben a fejezetben bemutatásra kerülnek a kutatás módszertana, a kutatási kérdések, illetve a kutatási eredmények.

\subsection{Kutatás módszertana}

A kutatás célja két hazai családi vállalkozás adott régió területi tőkéjére gyakorolt hatásának vizsgálata. A primer kutatás során két családi vállalkozás utódaival készített félig strukturált mély interjúkat készítettem, majd az interjúk alapján leszürt eredményeket mutatom be összegezve. Mindkét családi vállalkozás generációváltás előtt áll. A családi vállalkozások kiválasztása saját, családi és baráti ismeretség alapján történt. Az interjúk elkészítésére 2019 nyarán került sor, a 2. táblázatban látható kérdések alapján.

A kutatás során a következő szempontokat vettük figyelembe:

- több, mint 10 éve múködő vállalkozások,

- KKV szektorból mikrovállalkozások,

- családi tulajdonú vállalkozások,

- utódlásban érintett vállalkozások,

1. táblázat Családi vállalkozások adatai

\begin{tabular}{ccc}
\hline Vállalkozás sorszáma & I. & II. \\
Szempont & 1991 & 2001 \\
Alapítás éve & mikro & mikro \\
Vállalkozás típusa & 35646 & 158749 \\
Nettó árbevétel (ezer Ft) 2018 & 2 fó & 3 fö \\
Foglalkoz-tatottak száma & &
\end{tabular}

Forrás: saját szerkesztés

2. táblázat Interjúkérdések

\begin{tabular}{|c|c|c|}
\hline & Kérdések a generációváltás elött álló családi vállalkozásoknak & \\
\hline 1 & $\begin{array}{l}\text { Milyennek értékeli a vállalkozása helyi szintű kapcsolatait és tevékenységét? Melyek ezen } \\
\text { kapcsolatok fórumai? Mik a vállalkozás helyi hálózatai? }\end{array}$ & \multirow{6}{*}{$\begin{array}{l}\text { Társadalmi } \\
\text { tőke elemeire } \\
\text { vonatkozó } \\
\text { kérdések }\end{array}$} \\
\hline 2 & $\begin{array}{l}\text { Milyen a kapcsolata a vállalkozásának az önkormányzattal? Miben nyilvánul ez meg? } \\
\text { Említsen együttmüködési tevékenységet! }\end{array}$ & \\
\hline 3 & $\begin{array}{l}\text { A vállalkozásnak milyen kapcsolódási pontjai vannak egyéni, illetve csoport szintjén a } \\
\text { társadalmi szervezetekben? }\end{array}$ & \\
\hline 4 & $\begin{array}{l}\text { Az Ön identitása - terület iránti elkötelezettsége - milyen módon befolyásolja a vállalat } \\
\text { beágyazottságát? }\end{array}$ & \\
\hline 5 & Ön szerint hatást gyakorol a helyi identitásra a vállalkozás? Hogyan? Milyen módon? & \\
\hline 6 & $\begin{array}{l}\text { A családi vállalkozások alapítóira jellemző erős regionális kötődés kimutatható-e a } \\
\text { további generációk esetében is? }\end{array}$ & \\
\hline
\end{tabular}


7 Milyen kapcsolatot ápol a vállalkozás az oktatási, kulturális intézményekkel? Hatással van-e a vállalkozás a város oktatási, illetve kulturális életére? Hogyan? Milyen módon?

8 Figyelembe veszi-e a vállalkozás a város polgárainak elképzeléseit az oktatás illetve kultúra alakításának területén?

9 Van-e szerepe - és ha igen, milyen- a vállalkozásnak a város tudásközvetítésében, illetve jövőalakításában?

10 A vállalkozás jelenlétével hatást gyakorol-e a város innovációs életére? Mit gondol, melyek ennek a fórumai, lépései, jelei: minden egyes együttmúködéssel hatással van a város innovációs életére?

11 Véleménye szerint a vállalkozás befolyásolja-e a város társadalmi szerkezetét, a polgárok értékrendjét? Hogyan?

12 Ön szerint hatást gyakorol-e a vállalkozás a város közösségépítésére, sikerességére?

Forrás: saját szerkesztés

\subsection{Kutatási kérdések}

A kutatásom témájával kapcsolatban az alábbi két kérdés fogalmazódott meg:

- Hogyan járulnak hozzá a családi vállalkozások a területi tőke gyarapodásához?

- Kimutatható-e összefüggés a vállalati regionális szerepvállalás és beágyazottság, valamint a területi töke között?

\subsection{Interjúk elemzése}

Az egyik családi vállalkozás megyei szinten elismert, de Ausztriából is bőven érkezik megrendelés. „A vállalkozás filozófiája nem engedi meg, hogy elégedetlenül távozzanak a vevők.” A helyi önkormányzattal békés a kapcsolat. Főként a személyes megbeszéléseket, újságban való tájékoztatást részesítik előnyben, de az online lehetőségek kihasználása sem elhanyagolható. (facebook, honlap). Minden esetben más és más eljárást kell alkalmazni és alkalmazkodni kell az adott vevőhöz/partnerhez. A vállalkozás jó kapcsolatot ápol az önkormányzattal, a vállalkozás indulásakor béreltek tőlük üzlethelyiséget, tehát több éves kapcsolatra tekinthet vissza. A helyi óvodákat és iskolákat folyamatosan támogatja a vállalkozás már évek óta. A vállalkozás számára piaci szempontból választott város Csorna. Érzelmi döntés az induláskor nem volt, ellenben a biztos vevőkör miatt ma már nem változtatna helyet. „Monopolhelyzet miatt nagymértékben gyakorol hatást a helyi identitásra a vállalkozás." Az óriási forgótőke és áruk miatt sok versenytársat megelőztek az évek során. Ennek az az egyszerü oka, hogy közel lehetetlen ugyanekkora választékú készlettel megjelenni a piacon. A vállalkozás havi szinten kapcsolatban áll óvodával és általános iskolával. „Támogatásra is sor kerül.” A vállalkozás ruhaanyagokat biztosít rendezvényekre, gyerekek számára. A vállalkozás nem veszi figyelembe a város polgárainak elképzeléseit az oktatás illetve kultúra alakításának területén, mivel a végső cél a profittermelés. A vállalkozásnak a város tudásközvetítésében nincs szerepe. A vállalkozás jelenlétével nem befolyásolja a város innovációs életét. A vállalkozás nem befolyásolja a város társadalmi szerkezetét. A vállalkozás nem gyakorol hatást a város közösségépítésére, sikerességére.

A másik vállalkozás rendelkezik országos szinten és külföldön is megrendelésekkel. Ebben a vállalkozásban nagyobb arányban van internetes megbeszélés, e-mail váltás vagy épp élőkamerás beszélgetés a távolság miatt. „Minden esetben más és más eljárást kell alkalmazni és alkalmazkodni kell az adott 
vevőhöz/partnerhez." Az állami megrendelések miatt üzleti kapcsolat áll fenn az önkormányzattal városi, megyei és országos szinten. Néhány havonta összegyült összeget egy-egy választott célra ajánlanak fel (például máltai szeretetotthon, állatmenhely, gyermekek támogatása). A vállalkozás nem beágyazott a régióba, hiszen irányítani egy iroda elegendő. „A távolság számunkra nem akadály. Ára van, de rajtunk nem múlik." Ez az oka a Németországban, Ausztriában és Szlovákiában folyó munkáknak. A vállalkozás kapcsolata a kulturális és oktatási intézményekkel elhanyagolható mértékű. A vállalkozás nincs különösebb hatással a város oktatási, illetve kulturális életére. „A vállalkozás nem veszi figyelembe a város polgárainak elképzeléseit az oktatás illetve kultúra alakításának területén, mivel a végső cél a profittermelés." A vállalkozásnak a város tudásközvetítésében nincs szerepe. A vállalkozás jelenlétével nem befolyásolja a város innovációs életét. A vállalkozás nem befolyásolja a város társadalmi szerkezetét. A vállalkozás nem gyakorol hatást a város közösségépítésére, sikerességére.

\section{4. Összegzés}

A két családi vállalkozással készített interjúk alapján a kutatási kérdéseimre az alábbi következtetéseket vontam le a két vállalkozásra vonatkozóan.

Mindkét családi vállalkozás stabil kapcsolatot ápol a partnerekkel, valamint stabil kapcsolattal rendelkezik a helyi önkormányzattal.

Mindkét családi vállalkozás oktatási intézményekkel kapcsolatban áll.

Mindkét családi vállalkozás társadalmi felelősségvállalás szempontjából szerepet vállal a régió életében, hiszen támogatnak alapítványokat, civil szervezeteket.

Mindkét családi vállalkozás esetén a családi vállalkozás alapítói és a gyermekeik is erősen kötődnek a régióhoz, illetve az alapító regionális kötődése kimutatható a következő generációkon is.

\section{Felhasznált irodalom}

Csákné Filep, J. (2012): Family businesses-focusing on succession. http://phd.lib.unicorvinus.hu/660/2/Csakne_Filep_Judit_den.pdf [Letöltve: 2015.04.15.]

Gersick, K. - Davis, J. - McCollom, M. - Lansberg, I. (1997): Generation to Generation: Life Cycles of the Family Bussiness. Harvard Bussiness School Press, Boston.

Konczosné Szombathelyi, M. (2015b): Chinese family businesses in Hungary. In Kim-Shyan Fam - Pedro Quelhas Brito (eds.): Travel, Discover, Marketing. MAG Scholar Global Business, Marketing and Tourism Conference, Proceedings; (5. International Entrepreneurship Environment; 1. cikk: 1-20.) Porto (Portugal); Porto Business School. ISBN: 978-0-473-32089-8

Nagy, G. D. (2016): Társadalmi tőke és területi kötődés Magyarországon, Belvedere Meridionale, Szeged, 24-29., 38-40. 
OVERVIEW: cultural capital

http://www.oxfordreference.com/view/10.1093/oi/authority.20110803095652

799 [Letöltve: 2015.04.15.]

Pricewaterhouse Coopers (2008): Making a difference - the PricewaterhouseCoopers family business survey 2007/08, 1-60. http://www.pwc.com/gx/en/familybusiness-survey [Letöltve: 2020.01.10.]

Rechnitzer, J. (2016): A területi tőke a városfejlödésben - A Györ-kód, Dialóg Campus, Győr, 19-23. 